\title{
Achievements in civil intellectual property enforcement and recent initiatives within the Digital Single Market Strategy on the regulatory environment for platforms and online intermediaries
}

\author{
Florence Hartmann-Vareilles ${ }^{1}$
}

Published online: 22 June 2017

(C) ERA 2017

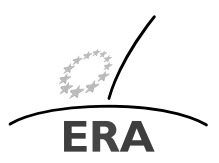

EUROPÄISCHE RECHTSAKADEMIE ACADEMY OF EUROPEAN LAW ACADEMIE DE DROIT EUROPEEN ACCADEMIA DI DIRITTO EUROPEO TRIER - TREVES - TREVIRI

\section{Illicit trade in pirated and counterfeit goods in the European Union: a major global challenge for the economy}

Since the adoption and the implementation of an EU legal framework less than fifteen years ago in order to tackle the infringement of intellectual property rights through civil and customs measures, illicit trade in pirated and counterfeit goods has remained a major global challenge. ${ }^{1}$

Such practices have negative impacts on the turnover of affected firms, causing damage to their reputation and generating high monitoring and enforcement costs. The phenomenon is aggravated by the fact that copyright pirates and counterfeiters are two or three steps ahead of law enforcers, and are getting extremely sophisticated in their infringement techniques. The high costs and complexity of litigation often dissuade smaller companies from enforcing their intellectual property rights. The worldwide reach of the internet, the facility to use online payments and the anonymity gained through operating via the internet are all factors which facilitate counterfeit sales of goods and services online. This is accentuated all the more by the existence of a certain level of tolerance, a lack of awareness or even sometimes

\footnotetext{
${ }^{1}$ For an evaluation of the costs associated with intellectual property infringements, see the range of publications prepared by the European observatory on infringements of intellectual property rights at https://euipo. europa.eu/ohimportal/en/web/observatory/observatory-publications.
}

F. Hartmann-Vareilles

fhartmann@era.int

1 Head of Section, Business Law Section, Academy of European Law (ERA), Metzer Alle 4, 54295 Trier, Germany 
a tendency on the part of some internet users to ignore or to play down the potential economic and legal consequences of intellectual property infringement.

\section{Tackling counterfeit in the European Union via civil enforcement measures: implementation difficulties}

Directive 2004/48/EC on the civil enforcement of intellectual property rights (IPRED) was adopted in 2004 in order to compel Member States to provide right holders with minimum civil judicial measures and remedies in order to enforce their intellectual property rights. ${ }^{2}$ The carrying out of a first evaluation on its implementation six years later did not prove to be very conclusive due to the late implementation of the directive in Member States. A public consultation launched in November 2012 provided further guidance but still offered an incomplete picture, as it only focused on the functioning of key provisions of the directive. The results of a larger second public consultation on the evaluation and modernisation of the legal framework for the enforcement of intellectual property rights, published in mid-2016, enumerated a certain number of implementation difficulties, in particular regarding the online environment and the cross-border context.

The main criticisms raised by stakeholders in this second public consultation concerned the fact that some proceedings put in place by the directive are interpreted differently by national courts. This is for example the case for the right to request access to information on infringing goods in court proceedings where the judge has to balance this right with other rights like the protection of privacy of data. Other criticisms raised relate to the; difficulties in the cross-border execution of injunctions against intellectual property infringers; disparities in the size of damages awarded by national courts, and the lack of an EU legal framework governing the responsibility of internet intermediaries.

Of the 492 respondents, the judiciary and the legal profession complained that IPRED's very general principles had left too much scope for manoeuvre to Member States in the national transposition process, resulting in inconsistent rulings across national jurisdictions. Since its implementation into national laws, about twenty preliminary rulings have been made by the European Court of Justice underlining the important role of harmonisation played by the Court in that field. However, Directive 2004/48/EC being a minimum harmonisation instrument, national laws on intellectual property infringement can vary greatly. One of the most prominent example of disparities involves the legal regime applicable to injunctions against parties allegedly infringing intellectual property rights, whether granted as provisional and precautionary measures or on the merits of a case. As stated in Recital 23 of IPRED, The conditions and procedures relating to such injunctions should be left to the national law of the Member States. Disparities in the Member States' legal regimes governing injunctions against intermediaries whose services are used by a third party to infringe an intellectual property right (e.g., an internet service provider or a person who is

\footnotetext{
${ }^{2}$ Corrigendum to Directive 2004/48/EC of the European Parliament and of the Council of 29 April 2004 on the enforcement of intellectual property rights [2014] OJ L 195/16.
} 
part of a supply chain) are noteworthy. ${ }^{3}$ Whereas some Member States allow injunctions against an intermediary without having to prove its liability or responsibility stricto sensus, proof of active involvement of the intermediary in the infringement is imposed by other national laws.

\section{Online infringement of intellectual property rights: the role and responsibilities of online intermediaries in needs of review}

The liability of internet intermediaries is currently highly debated and deserve therefore further developments. The EU legal framework is here characterised by a piecemeal of EU instruments that is to be found in its copyright, enforcement and ecommerce directives. ${ }^{4}$ Whereas the EU legal framework applicable to intellectual property infringement requires Member States to ensure that right holders are in a position to apply for injunctions against intermediaries, the e-commerce directive, which is intended to encourage the economic growth of digital services relying on user-generated content by providing them with legal certainty, sets limitations on the type of obligations that can be imposed on intermediaries and prohibits liability under certain clearly circumscribed circumstances. The so called e-commerce directive's safe harbours are cross-cutting, applying beyond intellectual property infringement to all types of illegal online activity, but in the field of intellectual property, the European Court of Justice has been asked several times to give clarifications on the notion of intermediary and on the kind of legal orders that can be granted against it. ${ }^{5}$

Whereas the imposition of injunctive orders on internet service providers by "courts and administrative authorities" so as to "terminate or prevent an infringement" (e.g., take-down notices), is allowed any measure which would impose a general monitoring obligation is not permitted. This is because it would not respect a fair balance between, on the one hand, fundamental rights (in particular, freedom of expression and information) and the freedom to conduct business (as described in Articles 11 and 16 of the Charter of Fundamental Rights of the European Union) - and, on the other hand, the rights of intellectual property owners. ${ }^{6}$ On the contrary, the

\footnotetext{
${ }^{3}$ Art. 11 of Directive 2004/48/EC of the European Parliament and of the Council of 29 April 2004 on the enforcement of intellectual property rights states that Member States must ensure that rights holders can apply for an injunction against intermediaries whose services are used by a third party to infringe an intellectual property right, without prejudice to Art. 8(3) of the EU Information Society Directive (InfoSoc Directive) (2001/29/EC), which specifically states that the same applies for copyright.

${ }^{4}$ Directive 2001/29/EC of the European Parliament and of the Council of 22 May 2001 on the harmonisation of certain aspects of copyright and related rights in the information society [2001] OJ L 167/10; Corrigendum to Directive 2004/48/EC of the European Parliament and of the Council of 29 April 2004 on the enforcement of intellectual property rights [2014] OJ L 195/16; Directive 2000/31/EC of the European Parliament and of the Council of 8 June 2000 on certain legal aspects of information society services, in particular electronic commerce, in the Internal Market ('Directive on electronic commerce') [2000] OJ L $178 / 1$.

${ }^{5}$ See in this respect the most recent rulings adopted by the CJEU in Case C-494/15 Tommy Hilfiger Licensing LLC v Delta Center, EU:C:2016:582 and in Case C-484/14 Mac Fadden v Sony Music Entertainment Germany, EU:C:2016:689, where the CJEU clarifies that the notion of intermediary applies in the same manner to the online and off-line environment.

${ }^{6}$ Case C-70/10 Scarlet Extended SA v Société belge des auteurs, compositeurs et éditeurs SCRL (SABAM); Belgian Entertainment Association Video ASBL (BEA Video), Belgian Entertainment Association Music
} 
adoption of a measure requiring an internet access provider to block a user's access to a specific website could be considered appropriate. ${ }^{7}$

In L'Oréal versus e-Bay which is a leading trade mark infringement case regarding the liability of operators of internet marketplaces, the European Court of Justice clarified on the basis of the e-commerce directive, that the responsibility of the Online operator should be excluded when he has not played an active role allowing it to have knowledge or control of the data stored ${ }^{8}$ A service provider will be held liable only if it collaborates with one of the recipients of a service to undertake illegal acts 9 or where it plays an active role which gives it knowledge of, or control over, this data, instead of confining itself to providing that service neutrally by a mere technical and automatic processing of data provided by its customers. ${ }^{10}$ To be liable, he must be aware of illegal third-party content and must have knowledge of or control over the information being transmitted or stored.

The safe harbour principles created by the e-commerce directive as well as the cautious approach adopted by the European Court of Justice towards intermediaries' responsibilities have led to much criticism, most of all from right holders claiming for a change in the EU legal framework.

On the basis of its Communication of May 2015 on a Digital Single Market Strategy for Europe (DSM), the European Commission started an assessment of the role of online platforms. Interestingly, this evaluation goes far beyond intellectual property law, including any ways to tackle illegal content on the internet. ${ }^{11}$ The results of the public consultation on the regulatory environment for platforms, online intermediaries, data and cloud computing and the collaborative economy, which closed in January 2016, showed diverging views as to the liability regime under the e-commerce directive.

Intellectual property right holders generally reported on the growing use of protected content without their authorisation (by online platforms or through licensing agreements containing unfair terms). They consider this largely to be due to legal uncertainties and market power of certain platforms, and therefore asked for clarification at EU level of the rules applicable to online platforms using protected content. Right-holders from the music industry have the strongest approach on this issue.

Other stakeholders, representing different categories of respondents including users and social platforms, argued for the importance of freedom of expression (sharing content being for most of them considered to be a cornerstone of freedom of

ASBL (BEA Music) and Internet Service Provider Association ASBL (ISPA) according to which injunctions against internet access providers or hosting service providers which required them to install a system for filtering all electronic communications as a preventive measure, at their own expense and for an unlimited period, should be considered disproportionate.

${ }^{7}$ Case C-314/12 UPC Telekabel Wien; EU:C:2014:192.

${ }^{8}$ Case C-324/09 L'oréal versus e-Bay, EU:C:2011:474.

${ }^{9}$ Arts. 12, 13 and 14 of Directive 2000/31/EC of the European Parliament and of the Council of 8 June 2000 on certain legal aspects of information society services, in particular electronic commerce, in the Internal Market ('Directive on electronic commerce') [2000] OJ L 178/1.

${ }^{10}$ Case C-236/08 to C-238/08 Google France, EU:C:2010:159.

${ }^{11}$ Communication from the European Commission to the European Parliament, The Council, the European Economic and Social Committee and the Committee of the Regions: A Digital Single Market Strategy for Europe, (COM) 2015, 192 final (SWD (2015) 100 final). 
speech) and the crucial role played by the liability exemption under the e-commerce directive to online platforms. Most of them raised the need to prevent abusive noticeand-actions-procedures by putting in place safeguards like counter-notice procedures enabling content-providers to give their views on the alleged illegality of the online content.

Reforming the current EU legal framework applicable to online platforms implies the highly delicate task of establishing a balance between several highly sensitive fundamental rights at stake, such as the freedom of the intermediary to conduct a business (Article 16 of the Charter), the rights of its customers to the protection of their personal data (Article 8 of the Charter) and their freedom to receive and share information (Article 11 of the Charter). ${ }^{12}$

This could explain partly why for the moment, the EU institutions have not adopted any horizontal EU legal approach on this issue. The chosen way forward seems to be for now the adoption of a sectoral approach, which in the field of intellectual property law has manifested itself, for example, in a proposed measure in the copyright field, aimed at encouraging Member States to provide rules obliging service providers to take appropriate and proportionate measures to ensure the protection of user-uploaded works (for example by putting in place content recognition technologies). ${ }^{13}$ The compatibility of this proposed measure with the safe harbour principle provided in the e-commerce Directive is currently much debated, EU institutions being highly criticised by some academic circles of wanting to reform the e-commerce directive through the back door. ${ }^{14}$ Some interesting proposals have been made, such as the creation of a duty of care for online intermediaries, the proposal to introduce a secondary liability regime in EU law, and the creation of EU fair use doctrine following the model that already exists in the USA, which are all currently being discussed.

The discussions surrounding the future adoption of this proposal are hence expected to be very intense in the next months. However, if the debates enhanced by legislative initiatives are crucial in all democratic societies, adopting a piece of legislation is not always the best way to make systems change, most of all in the context of internet where the very rapid evolution of technology constantly raises new legal challenges.

The consensual approach adopted a few years ago by the European Commission towards measures aimed at making the different actors more accountable on the internet is also interesting in this respect. This has for example taken the form of Mem-

\footnotetext{
${ }^{12}$ Charter of Fundamental Rights of the European Union, Arts. 8, 11 and 16 [2000] OJ C 364/1.

${ }^{13}$ Article 13 of the Proposal for a Directive of the European Parliament and of the Council on copyright in the Digital Single Market, (COM) 2016/0593 final, 2016/0280 (COD), (SWD (2016) 301 final) (SWD (2016) 302 final). See also Recital 38 of the same Directive's Proposal which mentions that "Where information society service providers store and provide access to the public to copyright protected works or other subject-matter uploaded by their users, thereby going beyond the mere provision of physical facilities and performing an act of communication to the public, they are obliged to conclude licensing agreements with right holders, unless they are eligible for the liability exemption provided in Article 14 of Directive 2000/31/EC of the European Parliament and of the Council".

${ }^{14}$ See for example the open letter from 24 February 2017 sent by European Research Centres to Members of the European Parliament and the Council of the European Union, at http://www.create.ac.uk/policyresponses/eu-copyright-reform/.
} 
oranda of Understanding concluded between internet platforms and right holders committing the parties to undertake measures in order to better fight against counterfeiting of goods and services. In the same vein, "the follow the money" policy of the European Commission is part of new commercial-scale policy objectives aimed at convincing all the interested parties together (the advertising industry, intermediaries, content protection sector, online media, right owners, civil society, consumer organisations, brands and advertisers) to establish voluntary agreements at EU level in order to tackle illegal content and to minimise online sales of counterfeit goods. Even if limited to tackling large scale types of infringements and even if not containing any legally binding provisions, these initiatives are very welcome. 